\title{
A experiência da "sagrada humanidade" de Jesus na espiritualidade de Santa Teresa de Ávila
}

\author{
Orientadora: Profa. Lúcia Pedrosa de Pádua \\ Pesquisadora: Valéria da Silva Pereira \\ Fonte: $\mathrm{CNPq}$
}

\section{Introdução}

Esta pesquisa é um desdobramento da pesquisa anteriormente realizada sobre a oração-amizade como um caminho de humanização em Santa Teresa de Jesus. Aprofunda no processo espiritual dessa escritora e mística, em que vemos uma passagem da "doutrina comum" sobre Deus para uma experiência que toca a existência e a transforma. Este é um dos motivos pelos quais evocar, com os questionamentos do nosso hoje, as obras clássicas de Santa Teresa. No interior da existência espiritual de Santa Teresa, podemos observar suas escolhas, liberdade e discernimento. No processo há diferentes níveis de interpelação, como a atenção aos próprios movimentos psíquicos, as leituras realizadas, a convivência com a família, o grupo das amizades e um nível particularmente importante: a descoberta de Jesus Cristo como Deus humanizado, "sagrada Humanidade", com todas as consequências teológicas, antropológicas e existenciais desse fato. A interação entre estes fatores se dá de forma lenta e gradual na vida da santa de Ávila, resultando numa personalidade espiritual rica e consistente. A riqueza desta experiência explica boa parte do êxito de Teresa de Jesus na literatura espiritual universal, a declaração oficial e universal, por parte da Igreja, da Santa de Ávila como "Doutora de Igreja" em 1970 e o interesse multidisciplinar por sua vida e obra, que a atualidade demonstra. 


\section{Objetivos}

Pesquisar uma autora clássica da espiritualidade cristã do período moderno, como forma de compreender as bases da espiritualidade atual. Aprofundar no tema da experiência com a pessoa de Jesus Cristo, o Filho de Deus, a "sagrada Humanidade" a partir de uma obra fundamental da espiritualidade cristã, o Livro da Vida. Evidenciar a interrelação entre humanização e dinamização das relações humanas fundamentais.

770 ATeo, Rio de Janeiro, v. 23, n. 63, p. 756-770, set./dez.2019 